\title{
MODEL RESOLUSI KONFLIK DALAM MENGATASI INTOLERANSI PADA PEMBELAJARAN IPS DI SMA KOTA SINGKAWANG
}

\author{
Dina Anika Marhayani ${ }^{1)}$, Wasis Suprapto ${ }^{2)}$ \\ 1) STKIP Singkawang, Singkawang, Indonesia \\ E-mail: dinaanika89@gmail.com \\ 2) STKIP Singkawang, Singkawang, Indonesia \\ E-mail: wasissoeprapto@gmail.com
}

\begin{abstract}
Penelitian ini bertujuan mengembangkan model teoritk resolusi konflik dalam pembelajaran IPS di SMA Kota Singkawang. Secara rinci tujuan penelitian ini: 1) mengembangkan perangkat pembelajaran model teoritik resolusi konflik intoleransi dalam pembelajaran IPS; 2) untuk mengetahui hasil pengembangan perangkat pembelajaran model teoritik resolusi konflik intoleransi dalam pembelajaran IPS valid, praktis, dan efektif. Penelitian ini akan menghasilkan model yang berupa model teoritik resolusi konflik intoleransi dalam pembelajaran IPS. Target yang akan dicapai melalui penelitian ini adalah terbitnya sebuah karya ilmiah yang dapat memberikan wawasan dan pengetahuan bagi pembaca melalui publikasi ilmiah dalam jurnal nasional. Metode yang digunakan dalam penelitian ini adalah R\&D yang dilakukan selama 1 tahun. Metode yang digunakan dalam penelitian ini adalah pengembangan model Borg dan Gall dengan tahapantahapan sebagai berikut: Pengumpulan informasi awal, perencanaan awal, pengembangan produk, ujicoba produk awal, revisi produk, ujicoba lapangan 1, revisi produk, ujicoba lapangan 2, revisi produk, desiminasi dan implementasi. Pada penelitian ini hanya sampai pada revisi produk dan ujicoba hanya sampai pada ujicoba lapangan 1 karena mengingat keterbatasan waktu. Model teoitik resolusi konflik intoleransi dapat digunakan di sekolah-sekolah terutama sekolah yang memiliki siswa yang multi etnis. Dengan penggunaan model ini, diharapan dapat digunakan di sekolah-sekolah terutama pada tingkat SMA pada pembelajaran IPS.
\end{abstract}

Keywords: Model Resolusi Konflik, Intoleransi, Pembelajaran IPS

\section{INTRODUCTION}

Masyarakat Kota Singkawang merupakan masyarakat yang majemuk. Penduduk Kota Singkawang yang terdiri dari berbagai etnis yakni suku melayu, dayak, cina, Madura, Jawa dan etnis-etnis lainnya yang telah menyebar mendiami titik wilayah hampir di seluruh kota Singkawang. Karakteristik masyarakat Singkawang yang majemuk berpotensi menimbulkan intoleransi yang dapat memicu terjadinya konflik. Peristiwa serangan bom di Vihara Budi Dharma yang terjadi pada tanggal 14 November 2016. Setelah itu disusul dengan peristiwa pengerusakan patung naga yang terjadi pada tanggal 22 November 2016 (https://m.tempo.co/read/news/2016/11/14/058820123/setela h-bom-gereja-wihara-di-singkawang-dilempari-molotov). Haryanto (2012:229) juga menemukan indikasi intoleransi di kota Singkawang bahwa munculnya fenomena "larangan" mengikuti kegiatan Cap Go Meh di Singkawang, termasuk munculnya pawai tandingan untuk perayaan Cap Go Meh yaitu Pawai Maulud Nabi, karena memandang mengikuti kegiatan perayaan Cap Go Meh berarti mengikuti ibadah agama lain.

Di Indonesia, dari tahun ke tahun jumlah kasus intoleransi semakin mengkhawatirkan. Data Koordinator Desk Kebebasan Beragama dan Berkeyakinan (KBB) Komnas HAM menunjukkan jumlah kasus intoleransi pada tahun 2016 terus mengalami peningkatan jika dibandingkan dua tahun sebelumnya. Tren peningkatan kasus intoleransi mengkhawatirkan kebinekaan Indonesia. Pada tahun 2014, Komnas HAM mencatat terdapat 74 kasus intoleransi yang dilaporkan. Tahun 2015, jumlah pengaduan meningkat, yaitu 87 kasus. Tahun 2016 hampir 100 kasus (BPS, 2011).

Hasil Riset Kementrian Pendidikan juga menunjukkan adanya benih-benih intoleransi di dua SMA negeri dan dua SMA swasta di Salatiga, Jawa Tengah yakni masih adanya siswa maupun guru yang menganggap ketua OSIS 
seharusnya berasal dari kalangan beragama mayoritas, pemimpin harus yang seagama, memilih teman yang seagama atau pun satu etnis, dan masih ada yang memilih tidak mengucapkan selamat hari raya kepada orang yang beda agama(http://litbang.kemendagri.go.id/asal-muasalpenelitian-kemendikbud-dan-temuan-sikap-intoleransi-disekolah).

Masyarakat yang majemuk rawan terjadinya intoleransi, begitupula dengan masyarakat kota Singkawang. Data BPS 2016 menyebutkan bahwa 34.94\% Dayak, 33.84\% Melayu, 9.74\% Jawa, 8.17 Tionghoa, 6.27\% Madura, 3.13\% Bugis, $0.60 \%$ Batak, $0.50 \%$ Daya, $0.33 \%$ Banjar, dan $1.33 \%$ lainnya. Keanekaragaman etnis memberikan ciri khas bagi masyarakat Singkawang, namun juga dapat menimbulkan terjadi intolerasi di antara masyarakat. Haryanto (2012:229) mengemukakan bahwa interaksi sosial di Singkawang bersifat "kosmopolitanisme," yakni masyarakat di Singkawang hidup bersama, tetapi interaksi yang positif dan aktif dalam berhubungan terutama membangun kerukunan beragama hampir tidak ada. Oleh karena itu di Singkawang, menjadi rentan atau berpotensi menjadi ketidakrukunan apabila tidak ada upaya yang aktif untuk membangun kerukunan umat beragama. Masykuri (2001: 13) mengatakan bahwa toleransi tidak cukup hanya membiarkan atau tidak menganggu, tetapi lebih dari itu toleransi membutuhkan bantuan, dorongan, dukungan dan penghargaan terhadap eksistensi orang lain atau kelompok lain. Tiap pemeluk agama dituntut tidak hanya mengakui keberadaan dan hal agama lain, tetapi terlibat secara aktif dalam usaha memahami perbedaan dan persamaan guna tercapainya kerukunan hidup bersama di tengah kebhinekaan. Mencermati situasi ini tentu diperlukan sebuah pembenahan. Model pembenahan untuk mengatasi intoleransi masyarakat kota Singkawang dapat dilakukan diberbagai bidang misalnya pendidikan. Pendidikan punya peranan yang cukup sentral untuk menyiapkan generasi muda yang berkualitas. Generasi muda inilah yang nantinya dipersiapkan menjadi agen perubahan di masyarakat.

Berdasarkan alasan tersebut di atas, maka penelitian ini akan menghasilkan model resolusi konflik bagi siswa pada pembelajaran IPS. Model resolusi konflik ini di gunakan oleh siswa agar memiliki kemampuan dan keterampilan peserta didik dalam menyikapi dan memecahkan serta mengambil tindakan terhadap berbagai fenomena dan masalah-masalah sosial budaya yang terjadi dilingkungan masyarakatnya. Dalam implementasinya model resolusi konflik ini perlu diketahui indikator penyebab intoleransi di kalangan siswa SMA Singkawang. Setelah diketahui indikator penyebab intoleransi kemudian dikembangkan perangkat pembelajaran yang mengintergrasikan resolusi konflik dengan nilai-nilai toleransi dalam pembelajaran IPS. Hasil penelitian ini adalah sebuah perangkat pembelajaran model resolusi konflik yang mengintergrasikan resolusi konflik dengan nilai-nilai toleransi dalam pembelajaran IPS yang nantinya dapat digunakan oleh sekolah-sekolah lain di kota Singkawang.
Berdasarkan latarbelakang masalah, maka peneliti dapat merumuskan masalah yakni

1. Bagaimana pengembangan perangkat pembelajaran model teoritik resolusi konflik intoleransi dalam pembelajaran IPS?

2. Apakah hasil pengembangan perangkat pembelajaran model teoritik resolusi konflik intoleransi dalam pembelajaran IPS valid, praktis, dan efektif?

\section{METODE PENELITIAN}

\subsection{Tahapan-tahapan penelitian}

Metode yang digunakan dalam penelitian ini adalah pengembangan model Borg dan Gall (1979), dengan tahapan-tahapan sebagai berikut: Pengumpulan informasi awal, perencanaan awal, pengembangan produk, ujicoba produk awal, revisi produk, ujicoba lapangan 1, revisi produk, ujicoba lapangan 2, revisi produk, desiminasi dan implementasi. Pada penelitian ini hanya sampai pada revisi produk dan ujicoba hanya sampai pada ujicoba lapangan 1 karena mengingat keterbatasan waktu.

\subsection{Subyek Penelitian}

Subjek coba penelitian ini adalah sebanyak 3 Sekolah yakni SMA N 1 Singkawang, SMA N 2 Singkawang, dan SMA N 6 Singkawang. Alasan pemilihan ketiga SMA tersebut sebagai subjek coba disebabkan sekolah tersebut memiliki siswa yang multikultural sehingga rawan terjadinya intoleransi di antara siswa.

\subsection{Rancangan Penelitian}

Rancangan penelitian ini berupa prosedur pengembangan produk yang di kelompokkan ke dalam empat tahapan pengembangan. Tahapan dalam pengembangan yang dilakukan tersebut meliputi:

1. Pengumpulan informasi, meliputi:

a. Studi Lapangan. Melakukan wawancara untuk mengkaji intoleransi pada subjek penelitian.

b. Studi Pustaka. Mengkaji teori dan hasil-hasil penelitian yang relevan dengan penelitian yang akan dilakukan, mengkaji studi kurikulum, mengkaji silabus mata pelajaran IPS.

2. Perencanaan awal

3. Desain Pengembangan, meliputi: pengembangan perangkat pembelajaran dan instrumen penelitian

4. Memvalidasi perangkat pembelajaran kepada ahli, dilanjutkan dengan analisis dan revisi.

5. Uji Coba Produk awal

Ujicoba produk awal dengan jumlah siswa sebanyak 30 siswa.

6. Revisi hasil ujicoba

7. Ujicoba lapangan, meliputi:

Ujicoba lapangan 1 dilakukan di tiga sekolah di SMA N 1 Singkawang sebanyak 1 kelas, SMA N 2 
Singkawang sebanyak 1 kelas, dan SMA N 6 Singkawang sebanyak 1 kelas.

8. Penyempurnaan produk akhir

\subsection{Teknik Pengumpulan Data}

Berikut adalah beberapa teknik yang diperlukan untuk mengumpulkan data dalam penelitian ini yaitu:

\section{Teknik Wawancara}

Wawancara model ini dilakukan secara mendalam pada informan yang peneliti nilai dapat memberikan informasi. Peneliti mengambil perwakilan dari siswa sebanyak 15 orang, guru 15 orang, dan kepala 1 orang di SMA N 1 Singkawang, SMA N 2 Singkawang, SMA N 6 Singkawang. Wawancara mendalam dilakukan oleh peneliti sebagai upaya mencari indikator penyebab intoleransi sebagai bahan kajian untuk mengembangkan perangkat pembelajaran model teoritik resolusi konflik intoleransi.

\section{Angket}

Angket digunakan untuk mengetahui data tentang respon siswa terhadap pengembangan perangkat pembelajaran model teoritik resolusi konflik intoleransi. Angket dalam penelitian ini meliputi angket respon siswa dan angket penilaian untuk ahli.

\section{Observasi}

Observasi digunakan untuk memperoleh data keterlaksanaan pengembangan perangkat pembelajaran model teoritik resolusi konflik intoleransi. Instrumen yang digunakan dalam penelitian ini yakni lembar observasi kegiatan guru

4. Tes

Tes dalam penelitian ini berbentuk tes uraian. Instrumen penelitian berupa tes kemampuan siswa dalam mengatasi intoleransi.

\subsection{Teknik Analisis Data}

Analisis data dalam penelitian ini dilakukan melalui analisis kualitatif dan analisis kuantitatif. Analisis data secara deskriptif kualitatif dilakukan terhadap data hasil studi pendahuluan. Pada penelitian ini, analisis data secara kualitatif dilakukan dengan memberikan narasi yang logis sesuai dengan tujuan penelitian. Adapun yang dimaksud dengan data kualitatif dalam penelitian ini hanya sebatas data mengenai gambaran intoleransi di 3 sekolah yakni SMA N 1 Singkawang, SMA N 2 Singkawang, dan SMA N 6 Singkawang yang meliputi faktor-faktor penyebab intoleransi. Analisis kuantitatif yang dilakukan dalam penelitian ini meliputi:

1. Analisis Kevalidan

Analisis kevalidan didasarkan pada data hasil validasi ahli. Berikut langkah-langkah yang dilakukan.

a.. Tabulasi data

Tabulasi data dilakukan pada hasil validasi dosen ahli. Berikut pedoman penilaian kevalidan pada lembar penilaian Silabus, RPP, BSS, LKS, dan Tes Hasil Belajar.
Tabel 2.1

Pedoman penilaian lembar validasi Ahli Silabus, RPP, BSS, LKS, dan Tes Hasil Belajar.

\begin{tabular}{cl}
\hline Skor & \multicolumn{1}{c}{ Kriteria } \\
\hline 1 & Tidak Baik \\
2 & Kurang Baik \\
3 & Cukup Baik \\
4 & Baik \\
5 & Sangat Baik \\
\hline
\end{tabular}

b. Perhitungan Skor Data-rata Validasi ahli

Data skor penilaian kevalidan Silabus, RPP, BSS, LKS, Tes Hasil Belajar yang sudah ditabulasi, selanjutnya dihitung dengan skor rata-rata untuk tiap aspek. Berikut rumus yang digunakan.

$$
\bar{x}=\frac{\sum x}{n}
$$

$\bar{x}=$ rata-rata perolehan skor $\quad \sum x=$ jumlah skor yang diperoleh $\mathrm{n}=$ banyaknya butir pertanyaan

c. Kriteria Kevalidan Validasi Ahli Perangkat Pembelajaran (Silabus, RPP, BSS, LKS, Tes Hasil Belajar)

Kriteria kevalidan perangkat pembelajaran (Silabus, RPP, BSS, LKS, Tes Belajar)

$1,00 \leq \mathrm{V} \alpha \leq 1,80=$ tidak valid

$1,80 \leq \mathrm{V} \alpha \leq 2,60=$ kurang valid

$2,60 \leq \mathrm{V} \alpha \leq 3,40=$ cukup valid

$3,40 \leq \mathrm{V} \alpha \leq 4,20=$ valid

$4,20 \leq \mathrm{V} \alpha \leq 5,00=$ sangat valid

Keterangan $\mathrm{V} \alpha=$ rata-rata penilaian ahli

Khusus untuk soal tes dan angket, selain dilakukan validasi ahli, juga dilakukan uji coba di kelas uji coba. Validasi tes meliputi validitas item menggunakan product moment dengan kriteria (Arikunto, 2012: 89)

$0,800<r_{x y} \leq 1,000=$ derajat validitas sangat tinggi

$0,600<r_{x y} \leq 0,800=$ derajat validitas tinggi

$0,400<r_{x y} \leq 0,600=$ derajat validitas sedang

$0,200<r_{x y} \leq 0,400=$ derajat validitas rendah

$0,000<r_{x y} \leq 0,200=$ derajat validitas sangat rendah..

d. Perhitungan Validitas dan Reliabilitas Angket memakai program SPSS Versi 16.

e. Perhitungan validitas dan Reliabilitas Soal Tes

\section{1) Validitas Soal Tes}

\section{Rumus :}

$$
r_{X Y}=\frac{N\left(\sum X Y\right)-\left(\sum X\right)\left(\sum Y\right)}{\sqrt{\left\{N\left(\sum X^{2}\right)-\left(\sum X\right)^{2}\right\}\left\{N\left(\sum Y^{2}\right)-\left(\sum Y\right)^{2}\right\}}}
$$


Keterangan :

$r_{X Y}$ : koefisien korelasi antara skor butir soal dan skor total

$\mathrm{N} \quad$ : jumlah subyek

$\sum X:$ Jumlah skor tiap bitir soal

$\sum Y:$ Jumlah skor total

$\sum X Y \quad$ : Jumlah perkalias skor butir dengan skor total

$\sum X^{2} \quad$ : Jumlah kuadrat skor tiap butir soal

\section{$\sum Y^{2}:$ Jumlah kuadrat skor total}

\section{Kriteria :}

pengujian dikonsultasikan dengan harga product moment pada tabel dengan taraf

signifikan 5\%, jika $r_{X Y}>\mathrm{r}_{\text {tabel }}$ maka butir soal tersebut dikatakan valid.

\section{2) Reliabilitas Soal Tes}

Rumus :

$$
r_{11}=\left(\frac{n}{n-1}\right)\left(1-\frac{S_{i}^{2}}{S_{t}^{2}}\right)
$$

dengan:

$\mathrm{r}_{11}=$ koefisien reliabilitas perangkat tes

$\mathrm{n} \quad=$ banyak butir soal

$S_{i}^{2} \quad=$ jumlah varians skor tiap item

$S_{t}^{2} \quad=$ varians skor total

Rumus Varians butir soal.

Rumus varians total.

$$
S_{i}^{2}=\frac{\sum X^{2}-\frac{\left(\sum X\right)^{2}}{N}}{N}
$$

Keteranga:

$$
S_{t}^{2}=\frac{\sum Y^{2}-\frac{\left(\sum Y\right)^{2}}{N}}{N}
$$

$\mathrm{N}$ : Jumlah peserta

$\mathrm{X}$ : Skor pada tiap butir soal

$\mathrm{Y}$ : Jumlah skor total

Kriteria:

Jika $r_{11}>r_{\text {tabel }}$ maka butir soal dikatakan reliable.

Reliabilitas

Keterangan

$0,80<\mathrm{r} \leq 1,00 \quad$ Sangat tinggi

$0,60<\mathrm{r} \leq 0,80 \quad$ Tinggi

$0,40<\mathrm{r} \leq 0,60 \quad$ Cukup

$0,20<\mathrm{r} \leq 0,40 \quad$ Rendah

$0,00<\mathrm{r} \leq 0,20 \quad$ Sangat rendah

\section{Analisis Kepraktisan}

Analisis kepraktisan didasarkan pada angket respon siswa

1) Tabulasi hasil Angket siswa

Berikut skala penilaian angket respon siswa untuk pernyataan postif dan negative.
Tabel 2.2

Pedoman penilaian angket respon siswa

\begin{tabular}{ccc}
\hline $\begin{array}{c}\text { Skor } \\
\text { Negatif }\end{array}$ & $\begin{array}{c}\text { Skor } \\
\text { Positif }\end{array}$ & Kriteria \\
\hline 1 & 5 & Sangat Setuju (SS) \\
2 & 4 & Setuju (S) \\
3 & 3 & Tidak Setuju (TS) \\
4 & 2 & Kurang Setuju (KS) \\
5 & 1 & Sangat Tidak Setuju (STS) \\
\hline
\end{tabular}

2) Menghitung skor rata-rata penilaian

Rumus

$\mathrm{P}(\mathrm{s})=\frac{B(b)}{T X N} \mathrm{X} 100 \%$

Keterangan

$\mathrm{P}(\mathrm{s})$ : presentase siswa yang memilih suatu kategori

B (b) : banyak siswa yang memilih suatu kategori

$\mathrm{T}$ : Jumlah Butir Tanggapan

$\mathrm{N}$ : Jumlah Siswa

Tabel 2.3

Kriteria persentase respon

\begin{tabular}{cc}
\hline Nilai & Kriteria \\
\hline $10 \% \leq \mathrm{P}(\mathrm{b}) \leq 20 \%$ & Sangat jelek \\
$21 \% \leq \mathrm{P}(\mathrm{b}) \leq 40 \%$ & Jelek \\
$41 \% \leq \mathrm{P}(\mathrm{b}) \leq 60 \%$ & Cukup \\
$61 \% \leq \mathrm{P}(\mathrm{b}) \leq 80 \%$ & Baik \\
$81 \% \leq \mathrm{P}(\mathrm{b}) \leq 100 \%$ & Sangat baik \\
\hline
\end{tabular}

Perhitungan respon siswa

$\mathrm{P}(\mathrm{p})=\frac{B(p)}{T X N} \mathrm{X} 100 \%$

KETERANGAN

$P(p)$ : presentase respon tiap siswa yang memilih seluruh pernyataan

B (b) : banyak siswa yang memilih seluruh pernyataan

$\mathrm{T}$ : Jumlah Butir Tanggapan

$\mathrm{N}$ : Jumlah pernyataan

3. Analisis Keterlaksanaan

Lembar observasi keterlaksanaan pembelajaran model teoritik resolusi konflik intoleransi:

1) Tabulasi hasil Observasi

\section{Tabel 2.4}

Kriteria observasi keterlaksanaan pembelajaran model teoritik resolusi konflik intoleransi

\begin{tabular}{cc}
\hline Nilai & Kriteria \\
\hline $\mathrm{P} \geq 80 \%$ & Sangat baik \\
$60 \% \leq \mathrm{P}<80 \%$ & Baik \\
$40 \% \leq \mathrm{P}<60 \%$ & Cukup \\
$\mathrm{P}<40 \%$ & Kurang \\
\hline
\end{tabular}


2) Menghitung skor rata-rata penilaian

$$
\begin{gathered}
P i \frac{\text { Skor Total }}{\text { Banyaknya indikator keterlaksanaan pembelajaran }} \times 100 \% \\
P_{k}=\frac{\text { Jumlah presentase tiap pengamat }}{\text { Jumlah pengamat }}
\end{gathered}
$$

3. Analisis Kefektifan

Analisis kefektifan model pembelajaran di dasarkan pada pencapaian siswa dalam menyelesaikan tes hasil belajar. Nilai maksimal pada tes hasil belajar adalah 100 dengan Kriteria Ketuntasan Minimal (KKM) yang ditetapkan pada mata pelajaran sosiologi yaitu 75 . Berikut langkahlangkah menganalisis kefektifan.

a) Memberikan skor jawaban pada setiap butir jawaban yang diperoleh siswa berdasarkan rubrik penilaian yang telah dibuat.

b) Menjumlahkan skor yang diperoleh siswa.

c) Menghitung nilai yang diperoleh masing-masing siswa.

d) Mengkategorikan hasil tes siswa berdasarkan KKM yakni 75.

e) Melakukan tabulasi hasil tes siswa.

f) Menghitung ketuntasan tes siswa dengan analisis ruangan sampe 1 T-test

a. Uji Rata-rata Nilai Tes

Hipotesis yang akan diuji adalah

$\mathrm{H}_{\mathrm{o}}: \mu \leq 75$ (rata-rata hasil belajar paling besar 75)

$\mathrm{H}_{\mathrm{a}}: \mu \geq 75$ (rata-rata hasil belajar lebih dari 75)

Rumus uji statistic menggunakan $\mathrm{t}=\frac{\bar{X}-\mu_{0}}{\frac{S}{\sqrt{n}}}$ (Sugiyono,

2011: 96)

$\mathrm{t}=$ nilai $\mathrm{t}$ yang dihitung, selanjtnya disebut $\mathrm{t}_{\text {hitung }}$

$\bar{x}=$ rataan kelas eksperimen

$\mu_{\mathrm{o}}=$ nilai yang dihipotesiskan

$\mathrm{s}=$ varians kelas eksperimen

$\mathrm{n}=$ banyak data kelas eksperimen

Selanjutnyya hasil tersebut dibandingkan dengan nilai t table menggunkan derajat kebebasam $\mathrm{dk}=\mathrm{n}-1$ dan taraf signifikan $\alpha=5 \%$, dengan kriteria $\mathrm{H}_{0}$ ditolak jika $\mathrm{t}_{\text {hit }} \geq \mathrm{t}_{1}-\alpha, \mathrm{n}-1$ (Sugiyono, 2011: 97).

b. Uji Ketuntasan Klasikal

Uji ketuntasan klasikal digunakan untuk mengetahui ketercapaian kemampuan literasi matematis siswa dibandingkan dengan KKM siswa secara klasikal sebesar $75 \%$.

Hipotesis sebagai berikut:

$\mathrm{H}_{0}: \pi \leq 75 \%$ (proporsi ketuntasan siswa kurang dari atau sama dengan $75 \%)$

$\mathrm{H}_{1}: \pi>75 \%$ (proposisi ketuntasan siswa mencapai tuntas individual mencapai $75 \%$ )

Akan diuji proposisi dua pihak menurut Sudjana (2005) dengan menggunakan rumus:

$$
Z=\frac{\frac{x}{n}-\pi_{0}}{\sqrt{\frac{\pi_{0}\left(1-\pi_{0}\right)}{n}}}
$$

Keterangan:

$\mathrm{n}$ : jumlah sampel.

$\mathrm{X}$ : banyaknya peserta didik yang tuntas secara individual.

$\mathrm{Z}$ : nilai statistik hasil perhitungan.

$\pi_{0}$ : proporsi yang ditetapkan $(75 \%)$.

Diterima atau ditolaknya hipotesis dapat ditentukan oleh hasil perhitungan nilai $\mathrm{Z}$ yang dicocokkan dengan $\mathrm{Z}$ pada tabel, di mana $\mathrm{H}_{0}$ diterima jika $\mathrm{Z}_{\text {hitung }} \geq \mathrm{Z}_{0,5(1-\mathrm{a})}$.

\section{HASIL DAN PEMBAHASAN}

\subsection{Hasil Penelitian}

Hasil penelitian ini akan membahas pengembangan perangkat pembelajaran, hasil validasi, uji coba soal, hasil uji kepraktisan, dan hasil uji coba perangkat. Pengembangan model teoritik resolusi konflik intoleransi dapat mengatasi intoleransi pada siswa. Tahap-tahap yang telah dilakukan dijelaskan sebagai berikut:

\subsubsection{Tahap Pengumpulan informasi}

\subsubsection{Studi Lapangan}

Langkah pertama yang perlu dilakukan untuk mengembangkan model teoritik resolusi konflik intoleransi adalah mengidentifikasi intoleransi yang ada di sekolah. Berdasarkan kajian dari hasil wawancara yang dilakukan oleh kepala sekolah, guru, dan siswa di SMA $\mathrm{N} 1$ Singkawang, SMA N 2 Singkawang, dan SMA N 6 Singkawang dapat diperoleh sebagai berikut:

1) Kepala Sekolah

Di tiga sekolah, baik SMA N 1 Singkawang, SMA N 2 Singkawang, SMA N 6 Singkawang tidak ada perbedaan aturan baik siswa muslim maupun non muslim. Contoh siswa non muslim terlihat khusyuk melaksanakan kegiatan keagamaan yang berbarengan dengan pesantren Ramadhan. Sementara siswa muslim mengikuti pesantren kilat maka siswa yang bukan non muslim melakukan kegaitan sesuai dengan agamanya masing-masing. Pelaksanaan kegiatan dilaksanakan pada hari dan waktu yang sama. Masing-masing sekolah juga sudah memiliki guru matapelajaran agama dan menyediakan tempat ibadah untuk semua baik itu agama. Tidak ada sikap deskriminasi kepada siswa non muslim, guru-guru di SMA N 1, SMA N 2, dan SMA N 6 Singkawang memperlakukan siswa secara sama baik dalam pembelajaran maupun diluar pembelajaran. Hubungan antara siswa dan guru juga harmonis di masing-masing sekolah. Masing-masing sekolah memiliki cara tersendri dalam mengatasi konflik yang terjadi disekolah. Di SMA N 1 Singkawang, jika terjadi konflik di sekolah maka konflik diselesaikan oleh guru bimbingan konsling (BK). Berbeda dengan di SMA N 2 dan SMA N 6 Singkawang, jika terjadi konflik maka guru wali kelas menyelesaikan terlebih dahulu, apabila konflik belum bisa teratasi maka diserahkan ke guru BK dan selanjutnya diserahkan kepada kepala sekolah apabila guru BK tidak dapat menyelesaikannya. 
2) Guru

Tidak ada perbedaan perlakuan terhadap siswa muslim dan non muslim. Guru memperlakukan siswanya baik di dalam maupun diluar. Pada saat pembelajaran guru melakukan kegiatan pembelajaran tanpa deskriminasi seperti membentuk kelompok belajar yang anggotanya tidak hanya siswa muslim saja tetapi juga siswa non muslim, sehingga siswa muslim maupun non muslim menjalin hubungan yang baik dan jarang terjadi konflik di SMA N 1 Singkawang dan SMA N 2 Singkawang. Berbeda dengan SMA N 6 Singkawang yang sering terjadi konflik. Konflik dipicu karena saling mengejek antar siswa. Untuk strategi penanggannya, selama ini guru belum mempunyai strategi yang khusus untuk meminimalisir terjadinya konflik yang diakibatkan oleh intoleransi. Intoleransi belum dikaitkan dengan materi pembelajaran. Upaya yang dilakukan oleh guru apabila menemukan siswa yang berkonflik maka cara penyelesaiannya dengan sekedar memberikan nasihat dan kemudian diserahkan kepada guru bimbingan konseling (BK) untuk diselsaikan.

3) Siswa

Dari hasil wawancara ke tiga sekolah yakni SMA N 1 Singkawang, SMA N 2 Singkawang, dan SMA N 6 Singkawang dapat disimpulkan bahwa sebagian besar siswa muslim memberikan respon positif kepada siswa non muslim, walaupun ada beberapa siswa yang masih menunjukkan sikap intoleransinya. Siswa non muslim ikut adil pada acara-acara yang dilaksanakan sekolah, seperti peringkatan hari besar kelahiran Nabi Muhammad Saw. Perlakuan siswa non muslim juga sama dengan siswa muslim yang lebih banyak dari mereka, tanpa ada rasa minder/ malu dan rasa tersisihkan. Namun, ditemukan beberapa sikap siswa yang masih menunjukkan sikap intoleransi, seperti ada sekelompok siswa seperti geng yang hanya berteman dengan teman yang satu etnis. Bahkan ada beberapa siswa yang tidak mau mengucapkan hari raya ke siswa yang berbeda agama. Selain itu, ada siswa yang tidak mau datang ke rumah teman saat diundang untuk makan saat merayakan hari keagamaannya.

Dari hasil wawancara dapat disimpulkan bahwa intoleransi ada karena adanya deskriminasi yang dilakukan oleh sekelompok orang tertentu terhadap kelompok lain. Hal ini dikarenakan kurangnya saling menghargai maupun saling menghormati.

\subsubsection{Studi Pustaka}

Dalam penelitian ini kurikulum yang menjadi acuan adalah kurikulum 2013. Perangkat yang dikembangkan tidak sepenuhnya menurut Kurikulum 2013. Perangkat yang dikembangkan seperti Silabus dan RPP disesuaikan dengan kebutuhan dan model teroritik resolusi konflik intoleransi. Berdasarkan hasil analisis tersebut maka ditetapkan KD yang sesuai dengan materi yang kan dibahas pada penelitian ini ditunjukkan pada Tabel 2.4.

3.1.2. Tahap Pengembangan Perangkat Pembelajaran

\subsubsection{Tahap Perencanaan Awal}

Tahap perencanaan

a. Menyiapkan Silabus, antara lain mengkaji kompetensi inti dan kompetensi dasar, mengidentifikasi materi pembelajaran, melakukan pemetaan kompetensi, mengembangkan kegiatan pembelajaran, merumuskan indikator pencapaian, menentukan jenis penilaian, menentukan alokasi waktu, menentukan sumber belajar. Contoh silabus dapat dilihat pada lampiran 2 .

b. Menyiapkan RPP terlebih dahulu dengan mengkaji silabus, mengkaji buku siswa, mengembangkan kegiatan pembelajaran, penjabaran jenis penilaian, menentukan alokasi waktu, menentukan sumber belajar. Contoh RPP dapat dilihat pada lampiran 3 .

c. Menyiapkan Buku Suplemen Siswa

Menyiapkan Buku Suplemen terlebih dahulu dengan menganalisis kurikulum, sumber belajar, karakteristik siswa. Contoh buku suplemen siswa dapat dilihat pada lampiran 5.

d. Menyiapkan Lembar Kerja Siswa (LKS) terlebih dahulu dilakukan analisis kurikulum yakni kompetensi inti, kompetensi dasar, indikator, dan materi pembelajaran; menyusun peta kebutuhan LKS, menentukan judul LKS, menulis LKS, menentukan alat penilaian. Contoh LKS dapat dilihat pada lampiran 6 .

e. Menyiapkan Tes Hasil Belajar dengan merumusankan tujuan tes hasil belajar, menetapkan aspek-aspek yang akan dievaluasi, memilih dan menentukan tehnik, menentukan tolak ukur, norma atau kriteria yang akan dijadikan pegangan atau patokan, menentukan frekuensi dari kegiatan evaluasi hasil belajar. Contoh Soal Tes Hasil Belajar dapat dilihat pada lampiran 7.

\subsubsection{Desain Pengembangan}

Pada tahap ini disusun Silabus, RPP, BSS, LKS, dan Tes Hasil Belajar yang sesuai dengan karaktersitik pembelajaran model teoritik resolusi konflik intoleransi pada materi permasalahan sosial. Perangkat pembelajaran yang dihasilkan disebut prototype 1 (awal) sebagai realisasi hasil perancangan model. Tahap-tahap pengembangan Silabus, RPP, Buku Suplemen Siswa, LKS, dan Tes Hasil Belajar, antara lain:

1. Rancangan Silabus

Tahap-tahap pengembangan silabus yang dipakai di sekolah dengan tahapan penyusunan silabus yang sudah dimodifikasi oleh peneliti. Untuk penilaian validator terhadap silabus didasarkan pada indikatorindikator yang termuat dalam lembar validasi silabus. Pada umumnya validator menyatakan silabus baik dan dapat digunakan dengan sedikit 
revisi. Berdasarkan hasil validasi ahli, beberapa revisi yang dilakukan terhadap Silabus dapat dilihat pada Tabel 3.1

Tabel 3.1

Revisi Silabus Berdasarkan Masukan dari Validator

\begin{tabular}{ll}
\hline \multicolumn{1}{c}{ Sebelum Revisi } & \multicolumn{1}{c}{ Setelah Revisi } \\
\hline Tidak ada indikator & Sudah ada indikator \\
$\begin{array}{ll}\text { Bentuk penilaian lebih } \\
\text { dirinci lagi }\end{array}$ & $\begin{array}{l}\text { Penilaian sudah dirinci } \\
\text { secara jelas }\end{array}$ \\
\hline
\end{tabular}

Bentuk akhir silabus yang dikembangkan setelah direvisi dapat dilihat pada lampiran 2 .

2. Rencangan Pelaksanaan Pembelajaran (RPP)

Tahap-tahap pengembangan RPP yang dipakai di sekolah dengan RPP yang telah dimodifikasi Penilaian validator terhadap RPP berdasarkan pada indikator-indikator yang termuat dalam lembar validasi RPP. Pada umumnnya validator menyatakan RPP baik dan dapat digunakan dengan sedikit revisi. Berdasarkan hasil validasi ahli, beberapa revisi yang dilakukan terhadap RPP dapat dilihat pada Tabel 3.2

Tabel 3.2

Revisi RPP Berdasarkan Masukan dari Validator

\begin{tabular}{lc}
\hline \multicolumn{1}{c}{ Sebelum Revisi } & Setelah Revisi \\
\hline $\begin{array}{l}\text { Belum ada alokasi } \\
\text { waktu }\end{array}$ & $\begin{array}{c}\text { Alokasi waktu sudah } \\
\text { dibagi secara rinci }\end{array}$ \\
\hline
\end{tabular}

Bentuk akhir RPP yang dikembangkan setelah direvisi dapat dilihat pada lampiran 3 .

3. Rancangan Buku Suplemen Siswa (BSS)

Tahap-tahap pengembangan BSS disesuaikan dengan kompetensi inti dan kompetensi dasar serta indikator yang akan dicapai. Dalam pengembangan BSS terdapat peta konsep serta petunjuk pengerjaan untuk tugas diskusi secara kelompok. Penilaian validator terhadap BSS berdasarkan pada indikatorindikator yang termuat dalam lembar validasi BSS. Pada umumnnya validator menyatakan BSS baik dan dapat digunakan dengan sedikit revisi. Berdasarkan hasil validasi ahli, beberapa revisi yang dilakukan terhadap RPP dapat dilihat pada Tabel 3.3.

Tabel 3.3

Revisi BSS Berdasarkan Masukan dari Validator

\begin{tabular}{ll}
\hline \multicolumn{1}{c}{ Sebelum Revisi } & \multicolumn{1}{c}{ Setelah Revisi } \\
\hline Buku BSS belum & Buku sudah disajikan \\
disajikan sesuai & sesuai model \\
model yang dipilih & $\begin{array}{l}\text { pembelajaran yang } \\
\text { dipilih }\end{array}$ \\
\hline
\end{tabular}

Bentuk akhir Buku Suplemen Siswa (BSS) yang dikembangkan setelah direvisi dapat dilihat pada lampiran 5.

4. Rancangan Lembar Kerja Siswa (LKS)

Penilaian validator terhadap Lembar Kerja Siswa (LKS) berdasarkan pada indikator-indikator yang termuat dalam lembar validasi Lembar Kerja Siswa (LKS). Secara umum validator menyatakan LKS baik dan dapat digunakan dengan revisi. Berdasarkan hasil validasi ahli, beberapa revisi yang dilakukan terhadap LKS dapat dilihat pada Tabel 3.4

Tabel 3.4

Revisi LKS Berdasarkan Masukan dari Validator Sebelum Revisi Setelah Revisi

\begin{tabular}{ll}
\hline Latihan soal belum & Soal sudah mencakup \\
mencakup semua & semua indikator yang \\
indikator & ada \\
Belum ada petunjuk & Sudah ada petunjuk \\
pengerjaan & pengerjaan \\
\hline
\end{tabular}

Bentuk akhir LKS yang dikembangkan setelah direvisi dapat dilihat pada lampiran 6.

5. Rancangan Tes Hasil Belajar

Tahap-tahap pengembangan Tes Hasil Belajar dengan membuat kisi-kisi, membuat soal, membuat pedoman peskoran. Penilaian validator terhadap Tes Hasil Belajar berdasarkan pada indikator-indikator yang termuat dalam lembar validasi Tes Hasil Belajar. Pada umumnnya validator menyatakan Tes Hasil Belajar baik dan dapat digunakan dengan sedikit revisi. Berdasarkan hasil validasi ahli, beberapa revisi yang dilakukan terhadap Tes Hasil Belajar dapat dilihat pada Tabel 3.5.

Tabel 3.5.

Revisi Tes Hasil Belajar Berdasarkan Masukan dari Validator

\begin{tabular}{|c|c|}
\hline Sebelum Revisi & Setelah Revisi \\
\hline $\begin{array}{l}\text { Soal yang dibuat belum } \\
\text { dibuat sesuai dengan } \\
\text { indikator yang akan } \\
\text { dicapai } \\
\text { Perhatikan waktu } \\
\text { dengan jumlah soal } \\
\text { Tidak ada pendoman } \\
\text { penskoran }\end{array}$ & $\begin{array}{l}\text { Soal yang dibuat sudah } \\
\text { sesuai dengan } \\
\text { indikator yang akan } \\
\text { dicapai. } \\
\text { Sesuai dengan waktu } \\
\text { dan jumlah soal } \\
\text { Sudah ada pedoman } \\
\text { penskoran }\end{array}$ \\
\hline
\end{tabular}

Bentuk akhir tes hasil belajar yang dikembangkan setelah direvisi dapat dilihat pada lampiran 7.

\subsubsection{Tahap Hasil Perangkat Pembelajaran 3.1.3.1 Ujicoba Tes Hasil Belajar}

Tes Hasil Belajar setelah divalidasi oleh validator, dilakukan uji coba soal tes hasil belajar 
guna memperoleh valid dan reliable di kelas X IPS 3 SMA N 6 Singkawang. Setelah dinyatakan valid, perangkat pembelajaran diuji cobakan di lapangan tahap awal di tiga sekolah yakni di SMA $\mathrm{N} 1$ Singkawang, SMA N 2 Singkawang, dan SMA N 6 Singkawang. Hasil revisi menghasilkan perangkat pembelajaran final yang disebut prototipe final. Rangkuman hasil penilaian validator dapat dilihat pada Tabel 3.6

Tabel 3.6

Rangkuman Hasil Validasi Ahli Perangkat Pembelajaran

\begin{tabular}{|c|c|c|c|c|c|c|}
\hline \multirow[b]{2}{*}{ No } & \multirow[b]{2}{*}{ Perangkat } & \multicolumn{3}{|c|}{ Validator } & \multirow{2}{*}{$\begin{array}{c}\text { Rera } \\
\text { ta }\end{array}$} & \multirow{2}{*}{$\begin{array}{c}\text { Krite } \\
\text { ria }\end{array}$} \\
\hline & & VI & V2 & $\begin{array}{l}\mathrm{V} \\
3\end{array}$ & & \\
\hline 1. & Silabus & 3,7 & 3,6 & $\begin{array}{c}3, \\
1\end{array}$ & 3,46 & Valid \\
\hline 2. & RPP & 3,7 & 3,6 & $\begin{array}{l}3 \\
7\end{array}$ & 3,66 & Valid \\
\hline 3. & BSS & 3,6 & 3,3 & $\begin{array}{l}3 \\
7\end{array}$ & 3,53 & Valid \\
\hline 4. & LKS & 3,8 & 3,8 & $\begin{array}{l}3, \\
8\end{array}$ & 3,8 & Valid \\
\hline 5. & Tes Hasil Belajar & 3,8 & 3,8 & $\begin{array}{l}3, \\
8\end{array}$ & 3,8 & Valid \\
\hline
\end{tabular}

Berdasarkan hasil validasi perangkat oleh validator menunjukkan bahwa perangkat yang dikembangkan dikatakan valid sehingga perangkat pembelajaran yang telah dikembangkan dapat digunakan dalam pembelajaran dengan sedikit revisi. Untuk hasil lembar angket respon siswa dikatakan valid dan reliabel dapat dilihat pada lampiran 10 . Hasil Tes Belajar selain divalidasi oleh para ahli juga dilakukan ujicoba. Hasil validitas Tes Belajar dikatakan valid apabila jika $r_{X Y}>\mathrm{r}_{\text {tabel }}$ dengan hasil sebagai berikut: $0,665644>0,361,0,639261>0,361$, $0.448279>0,361,0.591183>0,361,0.665644>0,361$, $0.639261>0,361, \quad 0.460195>3,61, \quad 0.573592>0,361$, $0.543191>0,361,0.689495>0,361$ dan reliabel dengan nilai $0.786>0.361$ kategori tinggi. Hasil validitas soal tes dapat dilihat pada lampiran 11 .

\subsubsection{Hasil Analisis Data Kepraktisan}

Pembelajaran pada kelas uijicoba perangkat dilaksanakan selama 2 kali pertemuan karena keterbatasan waktu penelitian. Pada pertemuan terakhir, keterlaksanaan perangkat oleh pengajar selama pembelajaran diamati oleh dua orang pengamat dengan menggunakan lembar validasi yang telah disusun sebelumnya. Setelah semua pertemuan selesai, siswa diberi angket untuk memberikan penilaian terhadap kegiatan pembelajaran dan perangkat pembelajaran yang dikembangkan (angket respon siswa). Data dari angket respon siswa diperlukan untuk memperoleh data kepraktisan dari perangkat pembelajaran yang dikembangkan. Lembar angket secara lengkap dapat dilihat pada lampiran 1.

\subsubsection{Keterlaksanaan Perangkat Pembelajaran}

Untuk mengetahui tingkat keterlaksanaan dan kegunaan perangkat pembelajaran, dilakukan pengamatan terhadap keterlaksanaan perangkat pembelajaran yang telah dikembangkan. Pengamatan dilakukan sebanyak dua kali oleh dua orang pengamat. Data hasil pengamatan dapat dilihat pada lampiran 12 Rekapitulasi data pengamatan keterlaksanaan perangkat pembelajaran ditunjukkan pada Tabel 3.7.

Tabel 3.7

Rekapitulasi Hasil Pengamatan Keterlaksanaan Perangkat Pembelajaran

\begin{tabular}{cccl}
\hline Pertemuan & SMA N 1 & SMA N & SMA N 6 \\
& \multicolumn{3}{c}{2} \\
\hline I & $82,81 \%$ & $82,81 \%$ & 82,81 \\
II & $82,81 \%$ & $75 \%$ & 89,06 \\
Total & $82,81 \%$ & $78,90 \%$ & $85,93 \%$ \\
Kriteria & Sangat & Baik & Sangat \\
& Baik & & Baik \\
\hline
\end{tabular}

Berdasarkan hasil rekapitulasi data pengamatan keterlaksanaan perangkat pembelajaran oleh dua orang pengamat, diperoleh skor $82,81 \%$ di SMA N 1 Singkawang dengan kriteria Sangat Baik, 78,90\% di SMA N 2 Singkawang dengan kriteria Baik, dan SMA N 6 Singkawang dengan skor 85,93\% dengan kriteria Sangat Baik.

\subsubsection{Respon Siswa}

Setelah kegiatan pembelajaran sebanyak dua kali pertemuan, di akhir pertemuan siswa diberi angket respon yang digunakan untuk mengetahui respon siswa terhadap perangkat pembelajaran. Hasil respon angket respon siswa dapat dilihat pada tabel 3.8

Tabel 3.8

Data Respon Siswa

SMA N 1 Singkawang

\begin{tabular}{llllllllllll}
\hline Pernyataan & 1 & 2 & 3 & 4 & 5 & 6 & 7 & 8 & 9 & 10 & 11 \\
Rata-rata & 77 & 76 & 78 & 81 & 71 & 74 & 80 & 76 & 85 & 82 & 76
\end{tabular}

SMA N 2 Singkawang

$\begin{array}{llllllllll}\text { Pernyataan } & 1 & 2 & 3 & 4 & 5 & 6 & 7 & 8 & 9\end{array}$

Rata-rata $\begin{array}{lllllllll}78.7 & 72.7 & 75 & 76.7 & 74 & 80 & 72 & 75.33 & 78\end{array}$

\begin{tabular}{llllllllll}
\multicolumn{10}{c}{ SMA N 6 Singkawang } \\
\hline Pernyataan & 1 & 2 & 3 & 4 & 5 & 6 & 7 & 8 & 9 \\
Rata-rata & 74 & 73.3 & 77 & 78 & 80 & 82.667 & 78 & 77.33 & 77.33
\end{tabular}

Berdasarkan hasil pengisian angket menunjukkan bahwa respon postif yang diberikan siswa berada pada kriteria Baik dengan rentan nilai $61-80 \%$ 


\subsubsection{Hasil Analisis Kefektifan Pembelajaran}

Data yang diperoleh dari Ujicoba perangkat pembelajaran dianalisis dan hasilnya digunakan untuk mengetahui kefektifan perangkat pembelajaran. Efektifitas perangkat pembelajaran diukur dengan

\section{a. Hasil Uji Normalitas}

Setelah mendapatkan data hasil belajar menggunakan model teoritik resolusi konflik dari postes, maka perlu diuji normalitas. Berdasarkan hasil perhitungan dengan SPSS diperoleh hasil uji normalitas pada Tabel 3.9.

\section{Tabel 3.9}

Output Uji Normalitas Hasil Belajar Siswa

Tests of Normality

Kolmogorov-Smirnov $^{\mathrm{a}} \quad$ Shapiro-Wilk

Statistic Df Sig. Statistic df Sig.

$\begin{array}{lllllll}\text { SMA_ } & .168 & 30 & .031 & .943 & 30 & .107 \\ 1 & & & & \end{array}$

a. Lilliefors Significance

Correction

Tests of Normality

\begin{tabular}{lrrrrrrr} 
& \multicolumn{3}{c}{ Kolmogorov-Smirnov $^{\mathrm{a}}$} & \multicolumn{4}{c}{ Shapiro-Wilk } \\
\hline SMA_ & Statistic & Df & Sig. & Statistic & df & \multicolumn{1}{c}{ Sig. } \\
\cline { 2 - 8 } 2 & .158 & 30 & .055 & .947 & 30 & .141 \\
\hline
\end{tabular}

a. Lilliefors Significance Correction

Tests of Normality

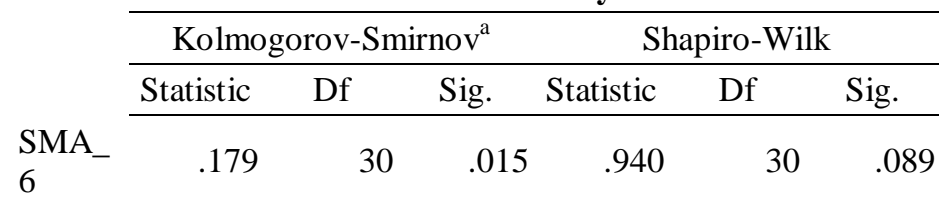

a. Lilliefors Significance Correction

Berdasarkan tabel diatas, nilai signifikasi Kolmogorov-Smirnov ${ }^{\mathrm{a}}$ sebesar 0,015, 0,055, dan 0,015 < 0,05, artinya data hasil belajar di SMA N 1 Singkawang, SMA N 2 Singkawang, dan SMA N 6 Singkawang berdistribusi normal.

b. Hasil Uji Ketuntasan

Ketuntasan belajar siswa setelah diberikan pembelajaran menggunakan model teoritik resolusi konflik intoleransi dalam penelitian ini dilihat dari berikut:

1) Uji Rata-Rata Nilai

Uji Rata-rata Nilai SMA N 1 Singkawang

$$
\mathrm{t}=\frac{\bar{x}-\mu_{0}}{\frac{s}{\sqrt{n}}}=\frac{81,67-75}{\frac{7,694}{\sqrt{30}}}=\frac{6,67}{\frac{7,694}{5,477}}=\frac{6.67}{1,404}=4,750
$$

Jadi diperoleh nilai $t_{\text {hitung }}=4.750$, Karena $t_{\text {hitung }}>$ $t_{\text {tabel }}$ atau $4.750>1,69$ ini berarti $\mathrm{H}_{0}$ ditolak dan $\mathrm{H}_{1}$ diterima. Jadi, kesimpulan yang diperoleh adalah rata-rata nilai tes siswa SMA N 1 Singkawang menggunakan pembelajaran model teoritik resolusi konflik intoleransi telah mencapai $\mathrm{KKM}=75$.

Uji Rata-rata Nilai SMA N 2 Singkawang

$$
t=\frac{\bar{x}-\mu_{0}}{\frac{s}{\sqrt{n}}}=\frac{81,83-75}{\frac{6,628}{\sqrt{30}}}=\frac{6,83}{\frac{6,628}{5,477}}=\frac{6,83}{1,210}=5,644
$$

Jadi diperoleh nilai $t_{\text {hitung }}=5,644$, Karena $t_{\text {hitung }}>$ $t_{\text {tabel }}$ atau 5,644>1,69 ini berarti $\mathrm{H}_{0}$ ditolak dan $\mathrm{H}_{1}$ diterima. Jadi, kesimpulan yang diperoleh adalah rata-rata nilai tes siswa SMA N 2 Singkawang menggunakan pembelajaran model teoritik resolusi konflik intoleransi telah mencapai KKM.

\section{Uji Rata-rata Nilai SMA N 6 Singkawang}

$$
\mathrm{t}=\frac{\bar{x}-\mu_{0}}{\frac{s}{\sqrt{n}}}=\frac{80.83-75}{\frac{7,437}{\sqrt{30}}}=\frac{5.83}{\frac{7,437}{5,477}}=\frac{5.83}{1,357}=4,296
$$

Jadi diperoleh nilai $t_{\text {hitung }}=4,296$, Karena $t_{\text {hitung }}>t_{\text {tabel }}$ atau 4,296>1,69 ini berarti $\mathrm{H}_{0}$ ditolak dan $\mathrm{H}_{1}$ diterima Jadi, kesimpulan yang diperoleh adalah rata-rata nilai tes siswa SMA N 6 Singkawang menggunakan pembelajaran model teoritik resolusi konflik intoleransi telah mencapai KKM.

2) Uji Klasikal

\section{Uji Klasikal SMA N 1 Singkawang}

\section{Hipotesis}

$\mathrm{H}_{0}: \pi \leq 75 \%$ (proporsi ketuntasan siswa kurang dari atau sama dengan $75 \%)$

$\mathrm{H}_{1: \pi}>75 \%$ (proposisi ketuntasan siswa mencapai tuntas individual mencapai $75 \%$ )

Rumus yang digunakan:

$\mathrm{Z}=\frac{\frac{\mathrm{x}}{\mathrm{n}}-\pi_{0}}{\sqrt{\frac{\pi_{0}\left(1-\pi_{0}\right)}{\mathrm{n}}}}$

Dengan: $n=30 ; \pi_{0}=0,75 ; x=27$

$z=\frac{\frac{27}{30}-0,75}{\sqrt{\frac{0,75(1-0,75)}{30}}}=\frac{0,9-0,75}{\sqrt{0,00625}}=\frac{0,15}{0,079}=1.898$

Jadi $Z_{\text {hitung }} 1.898>Z_{\text {tabel }} 1,645$, artinya proposisi ketuntasan siswa SMA N 1 Singkawang mencapai ketuntasan mencapai $75 \%$.

\section{Uji Klasikal SMA N 2 Singkawang}

Hipotesis

$\mathrm{H}_{0:} \pi \leq 75 \%$ (proporsi ketuntasan siswa kurang dari atau sama dengan $75 \%)$

$\mathrm{H}_{1: \pi}>75 \%$ (proposisi ketuntasan siswa mencapai tuntas individual mencapai $75 \%$ )

Rumus yang digunakan:

$$
\mathrm{Z}=\frac{\frac{\mathrm{x}}{\mathrm{n}}-\pi_{0}}{\sqrt{\frac{\pi_{0}\left(1-\pi_{0}\right)}{\mathrm{n}}}}
$$

Dengan: $n=30 ; \pi_{0}=0,75 ; x=28$ 


$$
\begin{gathered}
z=\frac{\frac{28}{30}-0,75}{\sqrt{\frac{0,75(1-0,75)}{30}}}=\frac{0,933-0,75}{\sqrt{0,00625}}=\frac{0,183}{0,079} \\
=2,320
\end{gathered}
$$

Jadi diperoleh nilai $Z_{\text {hitung }} 2,320>Z_{\text {tabel }} 1,645$, artinya siswa SMA N 2 Singkawang yang mencapai ketuntasan mencapai $75 \%$.

\section{Uji Klasikal SMA N 6 Singkawang \\ Hipotesis :}

$\mathrm{H}_{0:} \pi \leq 75 \%$ (proporsi ketuntasan siswa kurang dari atau sama dengan $75 \%)$

$\mathrm{H}_{1: \pi}>75 \%$ (proposisi ketuntasan siswa mencapai tuntas individual mencapai $75 \%$ )

Rumus yang digunakan:

$$
\begin{aligned}
& Z=\frac{\frac{\mathrm{x}}{\mathrm{n}}-\pi_{0}}{\sqrt{\frac{\pi_{0\left(1-\pi_{0}\right)}}{\mathrm{n}}}} \\
& \text { Dengan: } n=30 ; \pi_{0}=0,75 ; x=28 \\
& Z=\frac{\frac{28}{30}-0,75}{\sqrt{\frac{0,75(1-0,75)}{30}}}=\frac{0,933-0,75}{\sqrt{0,00625}}=\frac{0,183}{0,079} \\
& =2,320
\end{aligned}
$$

Jadi diperoleh nilai $Z_{\text {hitung }} 2,320>Z_{\text {tabel }} 1,645$, artinya siswa SMA N 6 Singkawang yang mencapai ketuntasan mencapai $75 \%$.

\subsection{Pembahasan}

Permasalahan dalam penelitian ini adalah bagimana mengembangkan mengembangkan perangkat pembelajaran model teoritik resolusi konflik intoleransi dalam pembelajaran IPS secara valid, praktis, dan efektif. Berdasarkan penelitian yang telah dilakukan, dapat diuraikan pembahasan hasil penelitian sebagai berikut.

\subsubsection{Karakteristik Perangkat Pembelajaran yang dikembangkan}

Berdasarkan permasalahan yang telah diuraikan pada bab I, dilakukan penelitian pengembangan perangkat pembelajaran model teoritik resolusi konflik intoleransi dalam pembelajaran IPS. Perangkat pembelajaran yang diperlukan dalam mengelola proses belajar mengajar dapat berupa Silabus, RPP, LKS, Tes Hasil Belajar, Media pembelajaran, serta Buku Ajar Siswa (Trianto, 2012). Sesuai dengan itu, perangkat yang dikembangkan dalam penelitian ini meliputi Silabus, RPP, Buku Suplemen Siswa (BSS), LKS, dan Tes Hasil Belajar Siswa. Sesuai dengan itu, pada penelitian ini Silabus dan RPP hasil pengembangan memiliki karakteristik mengintegrasikan materi dengan intoleransi serta indikator yang harus dicapai yaitu dalam materi gejala sosial (fenomena sosial) kelas X. Langkah-langkah pembelajaran model teoritik resolusi konflik terdiri dari lima tahap Lasmawan (2012: 21). Sesuai dengan hal itu, pada penelitian ini, langkah-langkah pembelajaran model teoritik resolusi konflik intoleransi yang digunakan adalah sebagai berikut:

1. Tahap identifikasi

Guru meminta siswa membagi pengalaman tentang intoleransi yang pernah dialami. Setelah itu dilakukan tanya jawab mengenai sikap intoleransi yang sering terjadi di kehidupan sehari-hari yang relevan. Diharapkan siswa dapat ikut terlibat aktif dalam membangun pengetahuannya.

2. Tahap eksplorasi dengan menyisipkan nilai-nilai toleransi

Guru menyampaikan materi gejala sosial (fenomena sosial) dengan memberikan contoh intoleransi yakni kasus tidak menghargai teman yang berbeda agama dan menyisipkan nilai-nilai toleransi seperti sikap menghargai perbedaan agama, suku, etnis, pendapat, sikap dan tindakan orang lain yang berbeda dari dirinya. Kemudian siswa diminta untuk menelusuri akar masalah dari kasus intoleransi dengan cara mendorong siswa mengungkapkan bukti-bukti kasus intoleransi secara bebas.

3. Tahap eksplanasi

Guru mengajak siswa untuk berdiskusi tentang masalah intoleransi secara berkelompok. Diharapkan siswa dapat mengembangkan wawasan.

4. Tahap negosiasi konflik

Guru membimbing siswa dalam mengembangkan sejumlah solusi alternatif dan memilih yang relevan untuk mewujudkan sikap toleransi.

5. Tahap resolusi konflik

Guru meminta siswa untuk menentukan tindakan dalam mengatasi masalah intoleransi

6. Penutup

Guru dan siswa menyimpulkan bersama-sama materi yang telah dipelajari.

Silabus dan RPP yang dikembangkan mengacu pada Kurikulum 2013 namun tidak sepenuhnya karena yang terpenting adalah mengembangkan perangkat pembelajaran model teoritik resolusi konflik intoleransi sesuai dengan permasalahan dan tujuan dalam penelitian ini. Sehingga walaupun nantinya kurikulum berganti-ganti, perangkat pembelajaran ini diharapkan tetap dapat digunakan.

Bahan ajar dalam penelitian ini adalah Buku Suplemen Siswa (BSS). Buku siswa merupakan panduan belajar baik di kelas maupun mandiri yang memuat materi pembelajaran (Trianto, 2012). Sesuai dengan itu, pada penelitian ini BSS memiliki karakteristik memuat pembelajaran intoleransi.

Lembar Kerja Siswa (LKS) yang dikembangkan disesuaikan dengan tujuan pembelajaran untuk setiap pertemuan dan diintegrasikan dengan intoleransi. Masalah di LKS dihubungkan dengan materi yang ada pada Buku Suplemen Siswa agar mudah untuk dipelajari.

Tes Hasil Belajar merupakan butir tes yang digunakan untuk mengetahui hasil belajar siswa setelah mengikuti kegiatan belajar mengajar (Trianto, 2012). Tes hasil belajar berisi soal-soal mengenai materi yang diajarkan yaitu gejala sosial (fenomena sosial) yakni intoleransi. Sehingga tes hasil belajar siswa dapat melihat sejauh mana kemampuan belajar siswa setelah diberikan pembelajaran dengan memanfaatkan perangkat pembelajaran yang dikembangkan. 


\subsubsection{Hasil Pengembangan Perangkat Pembelajaran yang valid}

Tahap pengembangan perangkat pembelajaran dimulai dengan menyusun prototipe awal. Menurut Nieveen (1999) perangkat pembelajaran dikatakan valid jika memenuhi validasi isi dan konstruk yang ditetapkan oleh para ahli dibidangnya dengan kriteria $\geq 75 \%$. Pada penelitian ini, perangkat prototipe awal divalidasi oleh ahli (tiga orang validator) kemudian dilakukan revisi-revisi sesuai saran dan kritik dari validator sehingga diperoleh prototipe 2 . Untuk soal hasil belajar dan angket selain divalidasi oleh validator, juga dilakukan uji coba di kelas. Selanjutnya perangkat pembelajaran prototipe 2 di uji cobakan di lapangan untuk mengetahui kepraktisan dan kefektifan perangkat pembelajaran tersebut. Selama proses uji coba perangkat dilakukan revisi-revisi perangkat sesuai dengan tuntutan lapangan sehingga diperoleh prototipe akhir. Berdasarkan hasil validasi tiga validator dengan langkah-langkah yang telah ditempuh, diperoleh rerata nilai untu perangkat pembelajaran antara lain:

a. Silabus

Rerata nilai silabus diperoleh 3,46. Pada umumnya validator menyatakan silabus cukup dan dapat digunakan dengan sedikit revisi. Menurut Validator, silabus yang dikembangkan perlu memperhatikan indikator yang ingin dicapai sehingga pembelajaran dapat tercapai sesuai dengan tujuan pembelajaran. Penjabaran kegiatan pembelajaran yang tertuang dalam silabus merupakan ringkasan kegiatan yang dilakukan dalam pembelajaran yang terdapat lebih rinci dalam RPP. Silabus yang dikembangkan relevan dengan model teoritik resolusi konflik intoleransi.

b. Rencana Pelaksanaan Pembelajaran (RPP)

Pada umunya validator menyatakan RPP cukup dan dapat digunakan dengan sedikit revisi. Hasil penilaian validator terhadap RPP rerata nilainya adalah 3,66. Menurut validator, RPP yang dikembangkan perlu memperhatikan alokasi waktu dan indikator yang perlu dicapai. Dalam RPP terdapat panduan langkah-langkah yang akan dilakukan oleh guru dalam kegiatan pembelajaran yang disusun dalam langkah-langkah pembelajaran yang dijabarkan dari silabus. Pentingnya sebuah RPP juga dapat menjadi kegiatan professional yang penting bagi guru sendiri, tidak hanya dalam memajukan pemahaman guru terhadap isi buku ajar, tetapi juga dalam pemikiran dan menerapkan metode pembelajaran yang baik.

c. Buku Suplemen Siswa (BSS)

Dalam penelitian ini buku ajar yang dikembangkan adalah dalam bentuk buku suplemen siswa dengan tujuan sebagai buku pendamping untuk buku siswa yang telah disediakan oleh Kemendikbud dalam kurikulum 2013. Rata-rata penilaian validator terhadap buku suplemen siswa adalah 3,53 yang berarti termasuk dalam kriteria baik. Pada umumnya validator menyatakan bahwa buku suplemen siswa yang dikembangkan baik dan dapat digunakan dengan sedikit revisi. Revisi pada buku suplemen siswa meliputi buku BSS belum disajikan sesuai model yang digunakan. Dengan tersedianya buku sumplemen siswa dapat memberikan kemudahan siswa dalam mempelajari setiap kompetensi yang harus dikuasainya.

d. Lembar kerja Siswa (LKS)

Rerata hasil penilaian validator terhadap LKS adalah 3,8 yang termasuk dalam kriteria cukup. Pada umumnya validator menyatakan LKS yang digunakan baik dan dapat digunakan dengan sedikit revisi. Berdasarkan masukan validator, maka LKS belum ada petunjuk pengerjaan dan soal belum mencakup indikator. Dalam penggunaannya di kelas, LKS yang dikembangkan dapat membantu siswa dalam memahami materi yang berkaitan dengan intoleransi.

d. Tes Hasil Belajar

Secara umum validator menyatakan bahwa tes hasil belajar sudah cukup dengan hasil penilaian validator sebesar 3,8. Beberapa masukan dari validator adalah soal belum mencakup indikator sehingga diperlukan revisi. Setelah dilakukan validasi oleh validator dilanjutkan dengan ujicoba di kelas. Ujicoba dilakukan untuk mendapatkan uji validitas dan realibilitas. Tes hasil belajar yang dikembangkan termasuk dalam tes subjektif berbentuk essay (uraian). Menurut Arikunto (2012: 17) tes bentuk essay merupakan jenis tes kemampuan belajar yang memerlukan jawaban yang bersifat pembahasan atau uraian kata-kata.

\subsubsection{Hasil Pengembangan Perangkat Pembelajaran yang Praktis}

Kepraktisan perangkat pembelajaran dilihat berdasarkan pertimbangan para ahli bahwa perangkat mudah digunakan bagi guru dan siswa. Data pengamatan keterlaksanaan perangkat pembelajaran oleh dua orang pengamat, diperoleh skor $82,81 \%$ di SMA N 1 Singkawang dengan kriteria Sangat Baik, $78,90 \%$ di SMA N 2 Singkawang dengan kriteria Baik, dan SMA N 6 Singkawang dengan skor $85,93 \%$ dengan kriteria Sangat Baik. Sedangkan untuk hasil pengisian angket terhadap hasil pembelajaran menggunakan model resolus konflik intoleransi mendapatkan respon positif dari siswa dengan kriteria Baik.

\subsubsection{Hasil Pembelajaran yang efektif}

\subsubsection{Hasil Uji Ketuntasan}

Rata-rata nilai tes siswa SMA N 1 Singkawang menggunakan pembelajaran model teoritik resolusi konflik intoleransi telah mencapai KKM 75 dengan $t_{\text {hitung }}$ $>t_{\text {tabel }}$ atau $4.750>1,69$. Rata-rata nilai tes siswa SMA N 2 Singkawang menggunakan pembelajaran model teoritik resolusi konflik intoleransi telah mencapai KKM 75 dengan nilai $t_{\text {hitung }} 5,644>1,69$. Rata-rata nilai tes siswa SMA N 6 Singkawang menggunakan pembelajaran 
model teoritik resolusi konflik intoleransi telah mencapai KKM 75 dengan nilai $t_{\text {hitung }}>t_{\text {tabel }}$ atau 4,296 >1,69.

\subsubsection{Uji Klasikal}

Proposisi ketuntasan siswa SMA N 1 Singkawang mencapai ketuntasan mencapai $75 \%$ dengan $Z_{\text {hitung }} 1.898$ $>\mathrm{Z}_{\text {tabel }} 1,645$, siswa SMA N 2 Singkawang yang mencapai ketuntasan mencapai $75 \%$ dengan nilai $Z_{\text {hitung }}$ $2,320>Z_{\text {tabel }} 1,645$, sedangkan siswa SMA N 6 Singkawang yang mencapai ketuntasan mencapai $75 \%$ dengan nilai $Z_{\text {hitung }} 2,320>Z_{\text {tabel }} 1,645$. Artinya proposisi ketuntasan siswa SMAN N 1 Singkawang, SMA N 2 Singkawang, dan SMA N 6 Singkawang telah mencapai ketuntasan mencapai $75 \%$.

\section{KESIMPULAN}

Kesimpulan dalam penelitian ini adalah model teoritik resolusi konflik intoleransi layak digunakan dalam proses belajar mengajar di dalam kelas. Model teoritik resolusi konflik intoleransi efektif dalam meningkatkan hasil belajar siswa. Respon siswa terhadap pembelajaran dengan menggunakan model teoritik resolusi konflik intoleransi adalah Baik.

\section{UCAPAN TERIMAKASIH}

Ucapan terimakasih kepada Bapak Andi Mursidi selaku Ketua STKIP Singkawang yang telah mendukung penelitian dan Kemenristekdikti yang telah memberikan kesempatan untuk melakukan penelitian.

\section{DAFTAR PUSTAKA}

Alfian, D. (2016). Model Toleransi dalam Eksegese Khotbah Areopagus. Surabaya: Jurnal Studi Agama-agama. Vol. 6, No. 2: 131-163.

Arikunto, Suharsimi. (2012). Prosedur Penelitian Suatu Pendekatan Praktek. Jakarta: Rineka Cipta

Badan Penelitian dan Pengembangan Kementrian Dalam Negeri. (2017). Asal Muasal Penelitian Kemendikbud dan Temuan Sikap Intoleransi di Sekolah. Di akses pada http://litbang.kemendagri.go.id.

Badan Pusat Statistik (BPS) Singkawang, 2016.

Borg, W.R \& Gall, M.D. (1979). Educational Research: An introduction. New York \& London: Logman.

Dunia, I Nyoman. (2010). Pengaruh Model Pembelajaran Resolusi Konflik Terhadap Prestasi Belajar Pkn Ditinjau Dari Pola Asuh Orang Tua. Bali: Journal Program Pascasarjana Universitas Pendidikan Ganesha. Vol. 7, No. 10: 1-13.
Farid, M. (2016). Dialog dan Toleransi Beragama di Kota Ambon: Perspektif Bekas Pejuang Muslim Ambon. Malaysia: International Journal of Islamic Thought. Vol. 9 (2016): 44-50.

Haryanto, J. (2012. Interaksi dan Harmoni Umat Beragama. Vol.2, No. 1 (Mei 2012).

Ismail, Faisal. (2014). Dinamika Kerukunan antar Umat Beragama. Bandung: Remaja Rosdakarya.

Lasmawan, W. (2012). Pengembangan Model Jurisprudensi Sosial dalam Pembelajaran PPKn di SMU Negeri 1 Bangli. (laporan penelitian) Tidak Diterbitkan. Singaraja: Lemlit IKIP Negeri Singaraja.

Masykuri, A. (2011). Pluralisme Agama dan Kerukunan Dalam Keagamaan. Jakarta: Penerbit Kompas.

Na'im, A., Syaputra, H. (2017). Kewarganegaraan, Suku Bangsa, Agama dan Bahasa Sehari-hari Penduduk Indonesia (Jakarta: Badan Pusat Statistik, 2011), https://www.bps.go.id/pdf (diakses pada 12 Januari 2017).

Nieveen, N. (1999). Prototyping to Reach Product Quality. Dalam Plomp, T; Nieveen, N; Gustafson, K; Branch, R.M; dan van den Akker, J (eds). Design Approaches and Tools in Education and Training. London: Kluwer Academic Publisher.

Pahlevi, A. (2016). Setelah Bom Gereja, Wihara di Singkawang Dilempari Molotov. Tempo. 14 November 2016. Tersedia: https://m.tempo.com.

Patterns of Collective Violence in Indonesia (1990-2003). 2004. United Nations Support Facility for Indonesian Recovery (UNSFIR).

Sapriya. (2009). Pendidikan IPS. Bandung: PT Remaja Rosdakarya.

Sugiyono. (2011). Metode Penelitian Kuantitatif, Kualitatif dan R\&D. Bandung: Afabeta.

Suharsimi, Arikunto. (2012). Prosedur Penelitian Suatu Pendekatan Praktis. Jakarta: PT Bina Aksara.

Sukardjo. (2008). Buku Pegangan Kuliah: Evaluasi Pembelajaran. Yogyakarta: Program Pascasarjana Universitas Negeri Yogyakarta.

Supardi. (2011). Dasar-Dasar Ilmu Sosial. Yogyakarta: Penerbit Ombak.

Tholkhah, Imam. (2013). Potensi Intoleransi Keagamaan Ssiswa Sekolah Di Jawa dan Sulawesi. Jakarta: Puslitbang dan Diklat Kementerian Agama Republik Indonesia.

Tillman, Diane. (2004). Pendidikan Nilai Untuk Kaum Muda Dewasa (Terjemahan Risa Pratono). Jakarta: Grasindo.

Trianto. (2012). Model Pembelajaran Terpadu. Jakarta: PT Bumi Aksara. 